\title{
Changes in authorship
}

(b) Correspondina author requests removal of author before publication

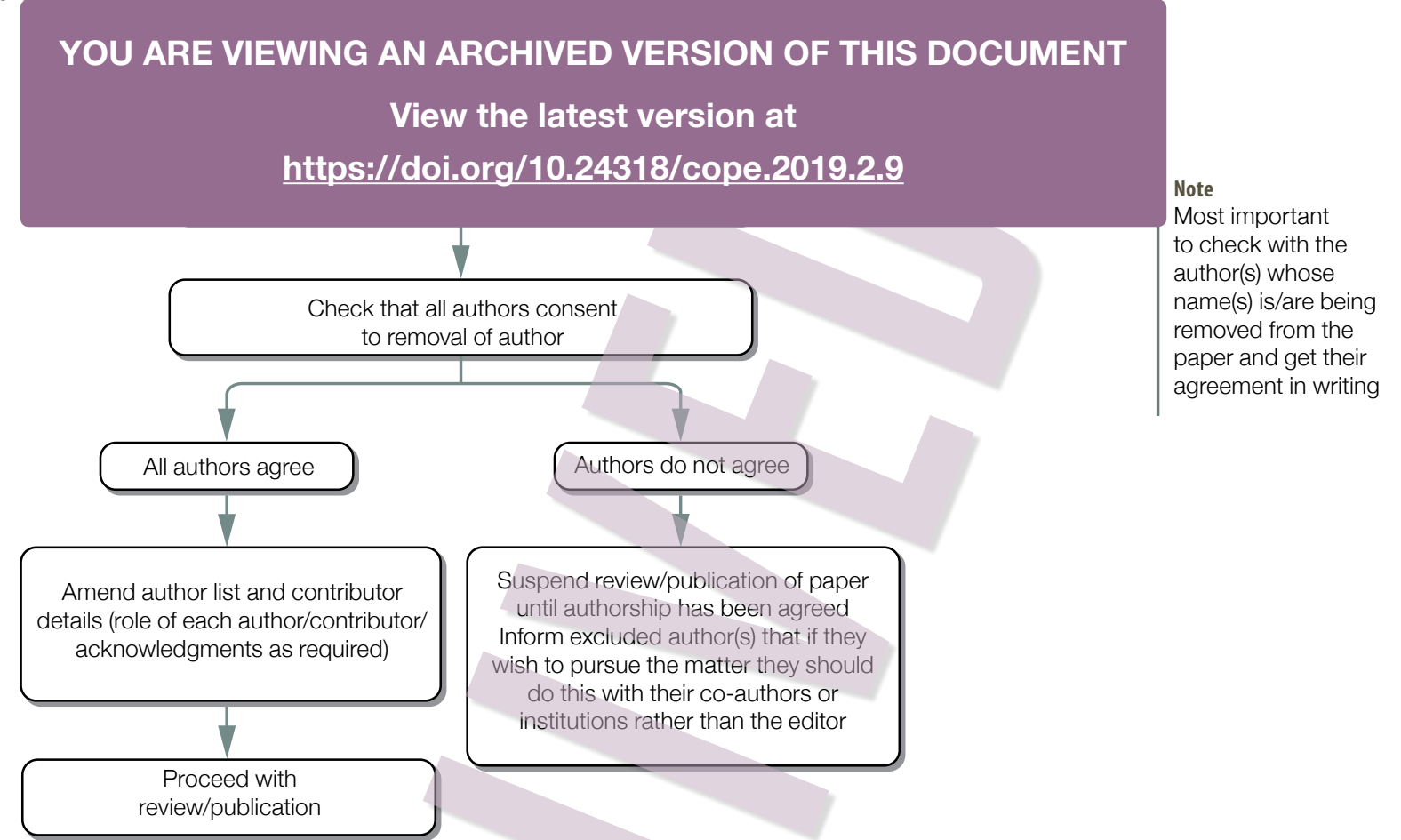

Developed for COPE by Liz Wager of Sideview (www.lizwager.com) (C) 2013 Committee on Publication Ethics First published 2006

A non-exclusive licence to reproduce these flowcharts may be applied for by writing to: cope_administrator@ publicationethics.org 